\title{
Innovation diagnosis in technology companies of a regional innovation system
}

\author{
Lindomar Subtil de Oliveira1', Márcia Elisa Soares Echeveste², Andriele De Prá Carvalho', \\ Melaine Camarotto' ${ }^{1}$, Paula Zarelli ${ }^{1}$
}

1Department of Humanities - Business area, Federal Technological University of Paraná, Francisco Beltrão, PR, Brazil. ${ }^{2}$ Department of Production Engineering, Federal University of Rio Grande do Sul, Porto Alegre, RS, Brazil.

How to cite: Oliveira, L.S., Echeveste, M.E.S., Carvalho, A.P. et al. (2020), "Innovation diagnosis in technology companies of a regional innovation system", Brazilian Journal of Operations \& Production Management, Vol. 17, No. 03, e2020997. https://doi.org/10.14488/BJOPM.2020.032

\section{ABSTRACT}

Goal: This article aims to diagnose the profile, strategies, and innovation practices adopted by the information technology companies of a Regional Innovation Systems (RIS).

Design/ Methodology/ Approach: This study was carried out with 19 small and medium companies from a RIS in the state of Paraná, where we collect data relating to the infrastructure and investments in $R \& D$, types of innovation projects, impact on revenue, activities of innovation, innovation protection methods, and information sources used by companies.

Results: The results showed that: companies with higher investments in R\&D, which generate innovative products and patents, have a higher financial return; the generation of patents is incipient among the companies surveyed; product process and organizational innovation are the main innovation activities carried out; there is some difficulty in establishing external partnerships for the development of innovation, especially with universities; customers, users, and the internet are the primary sources of information used by companies.

Limitation of the investigation: With respect to research limitations, we point out that our research sample is limited to 19 companies. Thus, for the results to be generalized, a larger sample is recommended.

Practical implications: The article showed that the launch of innovative products on the market has positive effects on the financial performance of companies due to increased sales.

Originality / Value: This paper offers a contribution to contextual studies of innovation in RIS. In addition, it presents an innovation profile of the technology companies of an RIS. These results can be used to compare and evaluate the innovation evolution in technology companies with other sectors and other RIS, or provide an indicator for the development of innovation policies for a region.

Keywords: Innovation; Collaborative innovation; Regional Innovation System; R\&D; Patent.

\section{INTRODUCTION}

In the current business context, innovation has become an imperative for competitiveness. Nowadays, a reconfiguration in the innovation and business model of companies, guided mainly by the more interaction of consumers, suppliers, and other partners in the development of products and innovation processes. In this sense, the business has been guided by the assimilation and use of external knowledge, especially through partnerships, collaborative research networks, alliances, and technological cooperation with universities (Bueno and Balestrin, 2012).

Financiamento: Fundação Araucária, Paraná, Brazil

Conflict of interest: The authors have no conflict of interest to declare.

Corresponding author: lindomar@utfpr.edu.br

Received: 11 June 2020

Accepted: 26 July 2020

Editor: Fernando Oliveira de Araujo and Chrystyane Abreu 
A first bridge to attract external knowledge and collaboratively develop innovation is to have a robust internal base of Research and Development (R\&D) (Spithoven et al., 2013; Chesbrough, 2012). External knowledge has a positive influence on the company's R\&D results (Kafouros and Forsans, 2012). Companies with more R\&D capabilities achieve more benefits from collaboration with external researchers, mainly by reducing time, better expertise in scientific research, and faster access to new knowledge (Fabrízio, 2009; Wynarczyk, 2013).

To promote innovation, technology, cooperation, and partnerships at the regional level, governments have continuously sought to strengthen the Regional Innovation Systems - RIS (Garcia and Chavez, 2014; Lundberg and Andresen, 2012). The RIS aims to foster innovation, technologies, and technical training, as well as to identify industrial demands, facilitating the relationship and interaction between companies, researchers, and other institutional actors (Tödtling and Trippl, 2005; Asheim and Coenen, 2005; Casali et al., 2010). One of the most critical factors in RIS is the ability of companies to generate innovations through cooperation with suppliers, customers, competitors, governments, and other organizations (Keupp and Gassmann, 2009; Lau and Lo, 2015; Tödtling and Kaufmann, 2001). Also, recent researchers highlight that RIS are favorable environments for collaboration for the development of innovation (Oliveira et al., 2017).

Based on this context, this article sought to identify the profile, strategies, and innovation practices adopted by the information technology companies of a RIS. The following aspects were addressed within the scope of the study: i) characterization of the company; ii) infrastructure and investments in R\&D; iii) types of innovation projects; iv) impacts on billing; v) innovation activities; vi) methods of protecting innovation; and vii) sources of information.

This article is structured in five sections including this introduction. The second section presents the theoretical framework. The third describes the methodology. Finally, the fourth section discusses the results, and the fifth presents the conclusions.

\section{COLLABORATIVE R\&D AND INNOVATION}

According to Tidd et al. (2008), "innovation is driven by the ability to establish partnership relationships, detect opportunities, and take advantage of them". Above all, research collaboration is a way to accelerate the launch and turnover of innovative products (Narula, 2004). Corroborating, other approaches highlight that an innovation system must be seen as an evolutionary, non-linear, interactive, and gradual process between the company and the external environment. This requires collaboration, synergy, intensive communication between multiple institutional agents, and the ability to create some knowledge flow through a network of partnerships (Rodrigues et al., 2013; Todtling and Trippl, 2005; Van Mierlo et al., 2010; Leydesdorff and Fritsch, 2006; Padilla-Pérez and Gaudin, 2014).

Some authors explain that the best performance in innovation is concentrated in large companies, since they have more resources and more structured R\&D centers (Quadros et al. 2001). De Jong et al. (2010), argue that companies should focus on internal R\&D departments to seek more external sources, mainly connecting universities. At this point, the company's ability to absorb external knowledge and integrate into its own R\&D activities, involving social interaction and qualification of employees, must be emphasized (Spithoven et al. 2011).

Regarding Small and Medium Enterprises - SMEs, despite the lack of resources being a barrier to innovation, it is also one of the reasons for these companies to seek technological knowledge and ideas outside their organizational borders (Spithoven et al. 2013). SMEs can seek trained personnel in consultancies, junior university enterprises, government incentive bodies, among others, without needing to have the best professionals in the market internally. Besides, they can elaborate R\&D more flexibly to allow the performance of other agents during the process (Silva and Dacorso, 2013).

Therefore, companies with only their competence would not be enough to develop a sustainable competitive advantage. In this sense, collaborative innovation aims to fill a knowledge gap so that companies can find partners to develop an innovative value chain (Lee et al. 2012). 


\section{METHODOLOGY}

\subsection{Sample, instrument, and research planning}

This research was carried out with a sample of 19 companies of Information Technology of the RIS of the Southwest Region, State of Paraná. It was characterized as an applied, descriptive, and quantitative study.

For data collection, an online questionnaire was used and sent by email to the managers of the selected companies. The research instrument was organized with 15 questions adapted from the PINTEC survey (Pesquisa de Inovação Tecnológica, 2014) and other authors in the literature (Appendix 1).

\section{RESULTS}

\subsection{Characterization of companies}

Firstly, a profile mapping of the surveyed companies was conducted. The data from this survey are summarized in Table 1.

Table 1. Profile of the surveyed companies

\begin{tabular}{|c|c|c|c|c|c|c|c|}
\hline \multirow[b]{2}{*}{$\begin{array}{l}\text { Activity } \\
\text { segment }\end{array}$} & \multicolumn{2}{|c|}{ Size } & Capital & \multicolumn{2}{|c|}{ Revenues } & \multicolumn{2}{|c|}{ Number of employees } \\
\hline & $\mathrm{S}$ & M & \multirow{2}{*}{$\begin{array}{c}100 \% \\
\text { national }\end{array}$} & $\begin{array}{c}\text { Up to } \\
2.4 \text { million }\end{array}$ & 15 & Up to 10 & 6 \\
\hline \multirow[t]{2}{*}{$\begin{array}{l}\text { Information } \\
\text { Technology } \\
\text { (IT) }\end{array}$} & 15 & 4 & & $\begin{array}{c}\text { More than } 2.4 \\
\text { and less than } \\
16 \text { million }\end{array}$ & 4 & 11 to 99 & 10 \\
\hline & & & & & & 100 to 499 & 3 \\
\hline
\end{tabular}

It was found that $78 \%$ of the surveyed companies are small and have revenues of up to 2.4 million. The other $22 \%$ are medium-sized companies with revenue of more than 2.4 to 16 million. All are national companies in the Information Technology segment.

\subsection{R\&D, types of projects and impact on revenue}

This section of the article presents data on investments and R\&D infrastructure, types of innovation projects, and billing data as shown in Table 2 .

Table 2. R\&D infrastructure, types of innovation projects, and billing

\begin{tabular}{|c|c|c|c|c|}
\hline & & Answers & Frequency & $\%$ \\
\hline \multirow{9}{*}{ 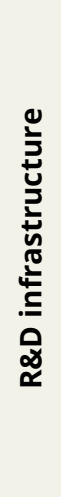 } & \multirow{2}{*}{ R\&D Department } & Yes & 9 & 47 \\
\hline & & No & 10 & 53 \\
\hline & \multirow{5}{*}{$\begin{array}{c}\text { Annual investment in } \\
\qquad \& D(R \$)\end{array}$} & Up to 10,000 & 7 & 37 \\
\hline & & From 10,000 to 50,000 & 8 & 42 \\
\hline & & From 50,000 to 100,000 & 1 & 5 \\
\hline & & From 100,00 to 500,000 & 2 & 11 \\
\hline & & Above 500.000 & 1 & 5 \\
\hline & \multirow{2}{*}{ R\&D employees } & Below 20 & 18 & 95 \\
\hline & & From 21 to 50 & 1 & 5 \\
\hline
\end{tabular}


Table 2. Continued...

\begin{tabular}{|c|c|c|c|c|}
\hline & & Answers & Frequency & $\%$ \\
\hline \multirow{12}{*}{ 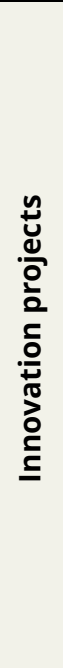 } & \multirow{4}{*}{$\begin{array}{l}\text { Incremental } \\
\text { innovation }\end{array}$} & Up to 20 projects & 16 & 84 \\
\hline & & From 21 to 50 & 2 & 11 \\
\hline & & From 51 to 100 & 1 & 5 \\
\hline & & Above 100 & 0 & 0 \\
\hline & \multirow{3}{*}{ Radical innovation } & Up to 20 projects & 18 & 95 \\
\hline & & From 21 to 50 & 1 & 5 \\
\hline & & From 51 to 100 & 0 & 0 \\
\hline & \multirow{5}{*}{ Revenue Increase } & Up to $20 \%$ & 9 & 47.5 \\
\hline & & From 21 to $40 \%$ & 6 & 31.5 \\
\hline & & From 41 to $70 \%$ & 1 & 5 \\
\hline & & Above $70 \%$ & 1 & 5 \\
\hline & & There was no increase & 2 & 11 \\
\hline
\end{tabular}

The results show that $53 \%$ of the companies do not yet have a structured R\&D department. This is a critical point, as the literature demonstrates, companies that have a solid structure in R\&D are more open to external knowledge and partnerships with universities (Spithoven et al. 2013; Ebersberger et al., 2012; Laursen and Salter, 2004).

In addition, it was also observed that the R\&D area or sector of the companies surveyed is small, since $95 \%$ of them had less than 20 employees involved in this activity. Capital investment in R\&D is another key element for invention, innovation, and increased productivity (Wynarczyk, 2013; Qiao et al. 2014). It was found that most companies (79\%) invest little in this area, allocating up to $R \$ 50,000$ annually to $R \& D$ activities. This result mainly portrays the reality of SMEs, characterized by the limitation of innovation activities, scarcity of resources in R\&D, and limitation of people (Qiao et al. 2014; Padilla-Pérez and Gaudin, 2014).

Concerning the number of projects developed, most companies have carried out up to a maximum of 20 incremental and / or radical innovation projects in the last five years. In the same period, $79 \%$ of the companies that launched innovative products on the market increased their sales by up to $40 \%$. Only $10 \%$ of companies reached a level higher than this percentage, and $11 \%$ of them did not achieve any growth.

It is possible to see that R\&D expenditures and internal and external innovation efforts to generate new products had a direct effect on financial performance of the companies. Thus, the greater the investments in this area, the greater are the returns and results for companies (Faems et al., 2010).

\subsection{Innovation activities, methods of protection, and sources of information}

In this research, it was also sought to identify the main types of innovation activities currently conducted by companies. As a result, respondents had the option of indicating more than one activity. As noted in Table 3, the values in the frequency column were obtained from the count of the number of times each activity was cited by the companies, respectively.

Table 3. Types of innovation activities

\begin{tabular}{ccc}
\hline Activities & Frequency & \% \\
\hline Training for innovation & 12 & 14,7 \\
\hline Marketing innovation & 7 & 8,5 \\
\hline Introduction of external knowledge & 12 & 14,7 \\
\hline External R\&D for innovation & 3 & 3,6 \\
\hline Internal P\&R for innovation & 11 & 13,5 \\
\hline Organizational innovation & 15 & 18,2 \\
\hline Product / process innovation & 16 & 19,5 \\
\hline Capital goods introduction & 6 & 7,3 \\
\hline Total & $\mathbf{8 2}$ & $\mathbf{1 0 0}$ \\
\hline
\end{tabular}


According to the results, product/process innovation and organizational innovation are predominantly the activities most implemented by companies. On the one hand, what drew attention was that the introduction of knowledge from external agents in the development of innovation was also one of the aspects that was very much mentioned (14.7\%). In contrast, it was noted that the use of external R\&D services for innovation is the least practiced activity by companies, with internal R\&D being the most used. The literature highlights the difficulty of companies in accepting and dealing with external partnerships (Burcharth et al., 2014).

Other information raised in the research dealt with the types of methods used to protect innovations and patent filings, as shown in the results in Table 4.

Table 4. Types of protection methods and patent filings

\begin{tabular}{cccc}
\hline \multirow{2}{*}{$\begin{array}{c}\text { Protection } \\
\text { methods }\end{array}$} & Answers & Frequency & \% \\
\cline { 2 - 4 } & Yes & 12 & 64 \\
& No & 7 & 36 \\
\hline \multirow{2}{*}{$\begin{array}{c}\text { Types of } \\
\text { methods }\end{array}$} & Trademark Registration & 8 & 42 \\
\cline { 2 - 4 } & Copyright & 8 & 42 \\
\hline \multirow{2}{*}{ Patent filings } & Software registration & 1 & 5 \\
\cline { 2 - 4 } & Industrial secret & 2 & 11 \\
\hline \multirow{2}{*}{ Time } & Up to 5 & 4 & 22 \\
& None & 15 & 78 \\
& Up to 3 years & 2 & 11 \\
\hline & 3 to 5 years & 1 & 11 \\
\hline
\end{tabular}

According to the Table 4, $64 \%$ of the surveyed companies use some type of method to protect their innovations. This result demonstrates the efforts of companies for innovation, since Intellectual Property is essential in the launch of new products and services (Spithoven et al., 2013). Given that many companies use more than one type of method, in this case it was also possible to mention all methods that are used. Thus, based on the frequency with which they were cited, the main methods used by companies are trademark registration and copyright.

Although $22 \%$ of companies have generated at least up to 5 patent filings in the past five years, $78 \%$ of them have made no deposit. Considering that the volume of patents filed is a way of measuring the generation of technological innovation (Reis, 2008; Bahia and Sampaio, 2015), this result reinforces what is recommended in the literature, that the number of patents generated is still reduced, especially in Brazil, where companies make little use of this tool as a competitive factor. Still, according to the response of the companies, $22 \%$ of them claim that a patent takes up to five years to be granted, while $73 \%$ of companies are unaware of this information.

Finally, concerning the sources of information sought by companies for the development of innovation, Table 5 presents the main results.

Among the internal sources of information, sales and marketing is the most used by companies, mainly because they are companies in the area of technology services. Regarding external sources, corroborating the results of Belussi et al. (2010) and Mina et al. (2014), the most frequent ones used by companies are the participation of customers and users in the development of innovation and the use of the internet. The latter is still highlighted by Burcharth et al. (2014); Billington and Davidson (2013) and Belussi et al. (2010), who all agree that the internet is a vital tool in solving problems, reducing costs, and improving communication and connectivity. 
Table 5. Sources of information for the development of innovation activities

\begin{tabular}{cccc}
\hline Dimension & Sources of information & Frequency & \% \\
\hline \multirow{2}{*}{ Internal } & Manufacturing R\&D & 6 & 31,5 \\
\cline { 2 - 3 } & Sales and MKT & 13 & 68,5 \\
\hline & Customers and users & 16 & 21 \\
\hline Business providers & 9 & 12 \\
\hline \multirow{2}{*}{ External } & Internet & 18 & 24 \\
& Magazine & 4 & 5 \\
& Conference and meetings & 9 & 12 \\
\cline { 2 - 3 } & Industry competitors & 5 & 7 \\
& Exposure & 7 & 9 \\
& Partnership with universities & 5 & 7 \\
& Machinery and Equipment supply & 2 & 3 \\
\hline
\end{tabular}

Comparing with the findings of Lee et al. (2010), it is clear that companies are increasingly seeking interaction and knowledge in the external environment for the development of innovation, mainly through customers, business partners, participation in meetings, exhibitions, etc. However, the result of the survey showed that the establishment of partnerships by companies, particularly with universities, is still unsatisfactory (7\%).

Again, this percentage shows the difficulty of small and medium business in making partnerships with universities or research centers. The literature highlights that large companies are more likely to have a relationship with universities, as they have more resources capable of better exploring new knowledge. In addition, they have more qualified people, better training, and a greater disposition for scientific research, which consolidates the relationship with universities (Janeiro et al., 2013).

\section{CONCLUSION}

This paper offers a contribution to contextual studies of innovation in RIS. The main objective was to diagnose the profile, some of the innovation strategies, and practices adopted by the information technology companies that are part of an RIS. The issues addressed in the study were: R\&D, types of projects and impact on company earnings, innovation activities, methods of protection, and sources of information used.

One of the positive results of the survey is that more than $60 \%$ of companies use some kind of method to protect their innovations. However, considering that patents are relevant information to assess the technological capacity of companies, it became evident that there is no culture among them aimed at generating patents. Even though the few companies that invested in these activities, as well as those that applied more resources in R\&D and launched innovative products on the market, obtained better financial performances.

Regarding the RIS, even though the spatial approximation between companies and universities is a fundamental element to promote collaborative innovation. It was evident by the results of the research that there is still some difficulty on the part of companies regarding the participation and acceptance of external knowledge for the generation of innovations, even though customers and users are one of the main sources of information pointed out by companies. Therefore, to produce a larger number of patents, an effective means is through partnerships between companies and research institutions, which can contribute to spreading innovation practices in companies.

As a proposal for future studies, it is suggested to deepen and expand the research instrument (Appendix 1), to be able to replicate and conduct similar studies in other contexts and different segments of companies, in different RIS at the state or national level, aiming comparative studies on the aspects covered, as well as concerning the results presented in this paper. 


\section{REFERENCES}

Asheim, B.T. and Coenen, L. (2005), "Knowledge bases and regional innovation systems: Comparing Nordic clusters", Research Policy, Vol. 34, No. 8, pp. 1173-90.

Bahia, D.S. and Sampaio, A.V. (2015), "Diversificação e especialização produtiva na geração de inovação tecnológica: Uma aplicação para os estados brasileiros", Revista de Administração e Inovação, Vol. 12, No. 3, pp. 109-34.

Belussi, F., Sammarra, A. and Sedita, S.R. (2010), "Learning at the boundaries in an Open Regional Innovation System: A focus on firms' innovation strategies in the Emilia Romagna life science industry", Research Policy, Vol. 39, No. 6, pp. 710-21.

Billington, C. and Davidson, R. (2013), "Leveraging open innovation using intermediary networks", Production and Operations Management, Vol. 22, No. 6, pp. 1464-77.

Bueno, B. and Balestrin, A. (2012), "Inovação colaborativa: Uma abordagem aberta no desenvolvimento de novos produtos", Revista de Administração de Empresas, Vol. 52, No. 5, pp. 517-30.

Burcharth, A.L.D.A., Knudsen, M.P. and Søndergaard, H.A. (2014), "Neither invented nor shared here: The impact and management of attitudes for the adoption of open innovation practices", Technovation, Vol. 34, No. 3, pp. 149-61.

Casali, G.F.R., Silva, O.M. and Carvalho, F.M.A. (2010), "Sistema Regional de Inovação: Estudo das regiões brasileiras", Revista de Economia Contemporânea, Vol. 14, No. 3, pp. 515-50.

Chesbrough, H.W. (2004), "Managing open innovation", Research Technology Management, Vol. 47, No. 1, pp. 23-6.

Chesbrough, H.W. (2012), "Open Innovation where we've been and where we're going", Industrial Research Institute, Vol. 55, No. 4, pp. 20-7.

De Jong, J.P.J., Kalvet, T. and Vanhaverbeke, W. (2010), "Exploring a theorethical framework to structure the public policy implications of open innovation", Technology Analysis and Strategic Management, Vol. 22, No. 8, pp. 877-96.

Ebersberger, B., Bloch, C., Herstad, S. et al. (2012), "Open Innovation Practices and their effect on innovation performance", International Journal of Innovation and Technology Management, Vol. 9, No. 6, pp. 1-23.

Fabrízio, K.R. (2009), "Absorptive capacity and the search for innovation", Research Policy, Vol. 38, No. 2, pp. 255-67.

Faems, D., De Visser, M., Andries, P. et al. (2010), "Technology Alliance Portfolios and Financial Performance: Value-Enhancing and Cost-Increasing Effects of Open Innovation", Journal of Product Innovation Management, Vol. 27, No. 6, pp. 785-96.

Garcia, B.C. and Chavez, D. (2014), "Network-based innovation systems: A capital base for the Monterrey city-region, Mexico", Expert Systems with Applications, Vol. 41, No. 12, pp. 5636-46.

Janeiro, P., Proença, I. and Gonçalves, V.C. (2013), "Open innovation: Factors explaining universities as service firm innovation sources", Journal of Business Research, Vol. 66, No. 10, pp. 2017-23.

Kafouros, M.I. and Forsans, N. (2012), "The role of open innovation in emerging economies: Do companies profit from the scientific knowledge of others", Journal of World Business, Vol. 47, No. 3, pp. 362-70.

Keupp, M.M. and Gassmann, O. (2009), "Determinants and archetype users of open innovation", $R \& D$ Management, Vol. 39, No. 4, pp. 331-41.

Lau, A.K.W. and Lo, W. (2015), "Regional innovation system, absorptive capacity and innovation performance: An empirical study", Technological Forecasting and Social Change, Vol. 92, No. march, pp. 99-114.

Laursen, K. and Salter, A.J. (2004), "Searching high and low: what type of firms use universities as a source of innovation", Research Policy, Vol. 33, No. 8, pp. 1201-15.

Lee, S., Park, G., Yoon, B. et al. (2010), "Open innovation in SMEs-An intermediated network model", Research Policy, Vol. 39, No. 2, pp. 290-300.

Lee, S.M., Olson, D.L. and Trimi, S. (2012), "Co-innovation: convergenomics, collaboration, and co-creation for organizational values", Management Decision, Vol. 50, No. 5, pp. 817-31.

Leydesdorff, L. and Fritsch, M. (2006), "Measuring the knowledge base of regional innovation systems in Germany in terms of a Tipple Helix dynamics", Research Policy, Vol. 35, No. 10, pp. 1538-53. 
Lundberg, H. and Andresen, E. (2012), "Cooperation among companies, universities and local government in a Swedish context", Industrial Marketing Management, Vol. 41, No. 3, pp. 429-37.

Mina, A., Moreau, E.B. and Hughes, A. (2014), "Open service innovation and the firm's search for external knowledge", Research Policy, Vol. 43, No. 5, pp. 853-66.

Narula, R. (2004), "R\&D collaboration by SMEs: New opportunities and limitations in the face of globalization", Technovation, Vol. 24, No. 2, pp. 153-61.

Oliveira, L.S.O., Echeveste, M.E.S., Cortimiglia, M. et al. (2017), "Analysis of determinants for Open Innovation Implementation in Regional Innovation Systems", Revista de Administração e Inovação, Vol. 14, No. 2, pp. 119-29.

Padilla-Pérez, R. and Gaudin, Y. (2014), "Science, technology and innovation policies in small and developing economies: The case of Central America", Research Policy, Vol. 43, No. 4, pp. 749-59.

Pesquisa de Inovação Tecnológica - Pintec (2014), Coordenação de Indústria. IBGE, Rio de Janeiro.

Qiao, P.H., Ju, X.F. and Fung, H.G. (2014), "Industry association networks, innovations, and firm performance in Chinese small and medium-sized enterprises", China Economic Review, Vol. 29, No. june, pp. 213-28.

Quadros, R., Furtado, A., Bernardes, R. et al. (2001), "Technological Innovation in Brazilian industry: An Assessment Based on the São Paulo Innovation Survey", Technological Forecasting and Social Change, Vol. 67, No. 2-3, pp. 203-19.

Reis, D.R. (2008). Gestão da Inovação Tecnológica, Manole, Barueri.

Rodrigues, R.F., Casarotto Filho, N. and La Rovere, R.L. (2013), "Redes de empresas e cooperação na formação do condomínio Tech Town", Revista Gestão \& Produção, Vol. 20, No. 3, pp. 713-25.

Serviço de Apoio às Micro e Pequenas Empresas - Sebrae (2014), available at: http://www. sebraepr.com.br (acessed 16 May 2014).

Silva, G. and Dacorso, A.L.R. (2013), "Inovação aberta como uma vantagem competitiva para a micro e pequena empresa", Revista de Administração e Inovação, Vol. 10, No. 3, pp. 251-68.

Spithoven, A., Clarysse, B. and Knockaert, M. (2011), "Building absorptive capacity to organise inbound open innovation in traditional industries", Technovation, Vol. 31, No. 1, pp. 10-21.

Spithoven, A., Vanhaverbeke, W. and Roijakkers, N. (2013), "Open innovation practices in SMEs and large enterprises", Small Business Economics, Vol. 41, No. 3, pp. 537-62.

Tidd, J., Bessant, J.R. and Pavitt, K. (2008), Gestão da Inovação, Bookman, Porto Alegre.

Tödtling, F. and Kaufmann, A. (2001), "The role of the region for innovation activities of SMEs", European Urban and Regional Studies, Vol. 8, No. 3, pp. 203-15.

Tödtling, F. and Trippl, M. (2005), "One size fits all? Towards a differentiated regional innovation policy approach", Research Policy, Vol. 34, No. 8, pp. 1203-19.

Van Mierlo, B., Leeuwis, C., Smits, R. et al. (2010), "Learning towards system innovation: Evaluating a systemic instrument", Technological Forecasting and Social Change, Vol. 77, No. 2, pp. 318-34.

Wynarczyk, P. (2013), "Open innovation in SMEs: A dynamic approach to modern entrepreneurship in the twenty-first century", Journal of Small Business and Enterprise Development, Vol. 20, No. 2, pp. 258-78.

Authors contributions: All the authors contributed equally to this paper.

* English translation, credits to: Rafael Medina dos Santos 


\begin{tabular}{|c|c|c|c|}
\hline Section & Matter & Variable & Reference \\
\hline \multirow{3}{*}{ 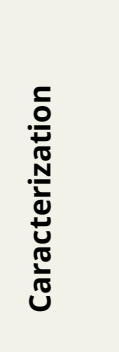 } & $\begin{array}{l}\text { 1. Operating } \\
\text { segment }\end{array}$ & [1] Industry / Manufacturing; [2] Service & \multirow{3}{*}{$\begin{array}{l}\text { (SEBRAE, 2014); } \\
\text { (Own } \\
\text { authorship) }\end{array}$} \\
\hline & $\begin{array}{l}\text { 2. Annual gross } \\
\text { revenue }\end{array}$ & $\begin{array}{l}\text { [1] Less than or equal to } 2.4 \text { million; [2] Greater } \\
\text { than } 2.4 \text { million and less than or equal to } \\
16 \text { million; [3] Greater than } 16 \text { million and less } \\
\text { than or equal to } 90 \text { million. }\end{array}$ & \\
\hline & $\begin{array}{l}\text { 3. Number of } \\
\text { employees }\end{array}$ & [1] Up to $10 ;$ [2] 11 to $99 ;$ [3] 100 to 499 & \\
\hline \multirow{14}{*}{ 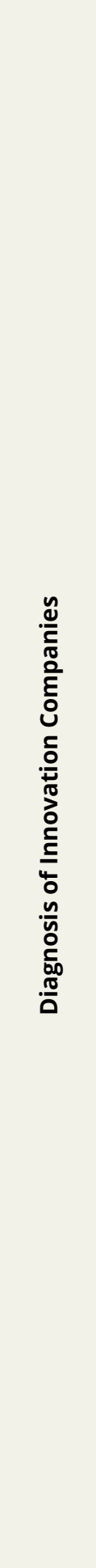 } & 4. Capital & [1] National; [2] Multinational & \multirow{7}{*}{ (Pintec, 2014) } \\
\hline & $\begin{array}{l}\text { 5. R\&D } \\
\text { department }\end{array}$ & [1] Yes; [2] No & \\
\hline & $\begin{array}{l}\text { 6. Investment in } \\
\text { annual R\&D }\end{array}$ & $\begin{array}{l}\text { [1] Up to 10,000; [2] Between } 10 \text { and 50,000; } \\
\text { [3] Between } 50 \text { and 100,000; [4] Between } 100 \text { and } \\
\text { 500,000; [5] Above 500,000 }\end{array}$ & \\
\hline & $\begin{array}{l}\text { 7. Employees } \\
\text { allocated to } \\
\text { R\&D }\end{array}$ & $\begin{array}{l}\text { [1] Less than 20; [2] From } 21 \text { to 50; } \\
\text { [3] From } 51 \text { to 100; [4] Above } 100\end{array}$ & \\
\hline & \multirow{2}{*}{$\begin{array}{l}\text { 8. Innovation } \\
\text { projects } \\
\text { (product, } \\
\text { process, or } \\
\text { service) } \\
\text { executed in the } \\
\text { last FIVE YEARS }\end{array}$} & $\begin{array}{l}\text { INCREMENTAL: [1] Up to 20; [2] From } 21 \text { to 50; } \\
\text { [3] From } 51 \text { to 100; [4] Above } 100\end{array}$ & \\
\hline & & $\begin{array}{l}\text { RADICALS: [1] Up to 20; [2] From } 21 \text { to 50; } \\
\text { [3] From } 51 \text { to } 100 ; \text { [4] Above } 100\end{array}$ & \\
\hline & $\begin{array}{l}\text { 9. Increase in } \\
\text { sales in the last } \\
\text { FIVE YEARS ... }\end{array}$ & $\begin{array}{l}\text { [1] Up to 20\%; [2] Between } 21 \text { and } 40 \% \text {; } \\
\text { [3] Between } 41 \text { and 70\%; [4] More than 70\%; } \\
\text { [5] Nonexistent }\end{array}$ & \\
\hline & $\begin{array}{l}\text { 10. Conducted } \\
\text { innovation } \\
\text { activities }\end{array}$ & $\begin{array}{l}\text { [1] Training for innovation; [2] Marketing } \\
\text { Innovation; [3] Introduction of external knowledge; } \\
\text { [4] External R\&D for innovation; [5] Internal R\&D } \\
\text { for innovation; [6] Organizational innovation; } \\
\text { [7] Product / process innovation; [8] Introduction } \\
\text { of capital goods; } \\
\text { [9] Other ... Specify [...] }\end{array}$ & (Lee et al., 2010) \\
\hline & $\begin{array}{l}\text { 11. Use of } \\
\text { methods to } \\
\text { protect ... }\end{array}$ & [1] Yes; [2] No & \multirow{3}{*}{ (Pintec, 2014) } \\
\hline & $\begin{array}{l}\text { 12. If so, what } \\
\text { types of ... }\end{array}$ & $\begin{array}{c}\text { [1] Invention patent; [2] Utility model patent; } \\
\text { [3] Registration of industrial design; [4] Trademark } \\
\text { Registration; [5] Copyright; [6] Industrial secret; } \\
\text { [7] Other ... Specify [...] }\end{array}$ & \\
\hline & $\begin{array}{l}\text { 13. Patent filings } \\
\text {... last FIVE } \\
\text { YEARS }\end{array}$ & $\begin{array}{l}\text { [1] Up to } 5 \text {; [2] } 6 \text { to } 10 ; \text { [3] } 11 \text { to } 20 ; \text { [4] Above 20; } \\
\text { [5] None }\end{array}$ & \\
\hline & $\begin{array}{l}\text { 14. Average } \\
\text { time for } \\
\text { patenting ideas } \\
\text { in the company }\end{array}$ & $\begin{array}{c}\text { [1] Up to } 3 \text { years; [2] } 3 \text { to } 5 \text { years; [3] } 5 \text { to } 10 \text { years; } \\
\text { [4] Over } 10 \text { years; [5] We do not know, as we have } \\
\text { not yet had patent registrations }\end{array}$ & $\begin{array}{l}\text { (Chesbrough, } \\
\text { 2004) }\end{array}$ \\
\hline & \multirow{2}{*}{$\begin{array}{l}\text { 15. Information } \\
\text { sources } \\
\text { (internal and } \\
\text { external) }\end{array}$} & $\begin{array}{c}\text { INTERNAL: [1] R\&D in Manufacturing; [2] Sales and } \\
\text { marketing; [3] Purchases; }\end{array}$ & \multirow{2}{*}{$\begin{array}{l}\text { (Lee et al., 2010); } \\
\text { (Belussi et al., } \\
\text { 2010). }\end{array}$} \\
\hline & & $\begin{array}{l}\text { EXTERNAL: [4] Customers and users; } \\
\text { [5] Competitors in the industry; [6] Raw material } \\
\text { suppliers; [7] Machinery and equipment suppliers; }\end{array}$ & \\
\hline
\end{tabular}




\begin{tabular}{ccc}
\hline Section & Matter & Variable \\
\hline [8] Business service providers; [9] Affiliates; \\
[10] Universities; [11] Government agency; \\
[12] Non-profit organizations; [13] Private research \\
centers; [14] Exhibition; [15] Internet; \\
[16] Magazine, Conference and meetings; \\
[17] Mass media (newspaper / TV); [18] Patents \\
\hline
\end{tabular}

